\title{
Towards a Clean and Sustainable Distributed Energy: The Potential of Integrated PEMFC-CHP
}

\author{
I. Aleknaviciute*, T. G. Karayiannis, M. W. Collins and C. Xanthos \\ School of Engineering and Design, Brunel University, London, Uxbridge, Middlesex, UB8 3PH, UK
}

\begin{abstract}
The use of fossil fuels within the current infrastructure for domestic energy supply is one of the main causes of anthropogenic emissions. The mitigation options to meet the ambitious carbon reduction targets set by the UK government are discussed in this paper, including the use of carbon capture and storage technology, clean renewable energy integration and a proposed system of integrated fuel cell combined heat and power (FC-CHP) technology. Analysis shows that the use of carbon capture and storage (CCS) technology within the current infrastructure can abate half the electricity associated $\mathrm{CO}_{2}$ emissions; however, this comes at a high cost penalty. The emissions associated with domestic heat cannot be prevented without changes in the energy infrastructure. Hydrogen powered fuel cells can provide clean energy at a range of scales and high efficiencies, especially when employed with a CHP system. However, production of $\mathrm{CO}_{2}$ free hydrogen is essential for fuel cell technology to contribute substantially to a low carbon economy globally. In this work three methods were investigated for small scale distributed hydrogen production, namely steam methane reforming, water electrolysis and cold plasma jet. The criteria used for comparisons include the associated $\mathrm{CO}_{2}$ emissions and the cost of energy production. Cold plasma jet decomposition of methane shows a high potential when combined with integrated FC-CHP technology for economically viable and $\mathrm{CO}_{2}$ free generation of energy, especially in comparison to water electrolysis. Including the value of the solid carbon product makes the plasma system most attractive economically.
\end{abstract}

Keywords: Clean energy, Hydrogen generation, Cold plasma jet

\section{Introduction}

\subsection{The hydrogen fuel cell future}

The global challenges in energy of growing oil scarcity, security of supply and environmental degradation are well documented, with the drive to develop a cleaner and more sustainable energy infrastructure [1-3] 'The built environment needs to develop more sustainable, less energy-intensive systems.......The UK government has identified the house building industry as a key sector in delivering carbon reduction' [4]. Domestic energy consumption for space and water heating, cooking, lighting and appliances is approximately $30 \%$ of total energy use in the UK and contributes $26 \%$ of total UK carbon dioxide emissions, with average household emissions of $78 \mathrm{~kg} \mathrm{CO} / \mathrm{m}^{2} / \mathrm{yr}$. Within a typical UK household, $58 \%$ of the energy is used for space heating, $24 \%$ for hot water and $19 \%$ for cooking, lighting and appliance use [4]. Hydrogen has long been recognised as a key alternative fuel to replace carbon based fossil fuels [5] in conjunction with fuel cell technology [1]. Hydrogen powered fuel cells can provide energy to the transportation sector as well as electricity to a wide range of products, from small portable items such as mobile phones and laptops, to domestic and industrial energy applications [5]. The advantages of hydrogen powered fuel cells include: (i) High efficiency - fuel cells convert fuel to electricity at more than twice the efficiency of internal combustion engines [6], and if heat generated by a fuel cell is utilized in CHP systems, 85\% efficiency can be achieved [2]; (ii) Zero emissions - hydrogen fuel cells emit only water and have no pollutant emissions [2]; (iii) Comfort - fuel cells are silent, vibration-free and require very little or no maintenance [6]; (iv) Providing energy at all

* Corresponding author. Tel.: 01895267082

E-mail: irma.aleknaviciute@ brunel.ac.uk

(c) 2014 International Association for Sharing Knowledge and Sustainability

DOI: 10.5383/ijtee.07.01.005 
scales - from micro power sources to multi-MW plants [6]. In 2003, the European Commission [5] stated that hydrogen and fuel cells are firmly established as strategic technologies that can meet the following objectives: (i) Maintaining economic prosperity and quality of life, and (ii) Achieving a sustainable energy system that meets the conflicting demands of increased energy supply and security, whilst maintaining costcompetitiveness, reducing climate change, and improving air quality. In 2003 the EC also announced a European hydrogen vision stating that by 2050 a hydrogen orientated economy would be globally implemented [5]. The use of fuel cells could well be more acceptable to residential markets for on-site domestic heat and electricity production, than engine-based technologies involving moving parts, noise and vibration [7]. The use of fuel cells can also reduce environmental emissions: carbon dioxide by $49 \%$, nitrogen oxide by $91 \%$, carbon monoxide by $68 \%$ and volatile compounds by $93 \%$ as compared with traditional combustion technologies [8]. Fuel cells applied to distributed energy systems have the highest efficiencies $(40-85 \%)$ when compared to conventional means such as the reciprocating diesel engine (35\%), turbine generator $(29-42 \%)$, photovoltaic $(6-19 \%)$ and wind turbine $(25 \%)$ [9].

\subsection{The PEMFC-CHP system}

The main advantages of Proton Exchange Membrane Fuel cells (PEMFCs) include their reliability and robustness [10]. PEMFCs are 'currently the ones with the most advanced technological development and some cogenerative units are already commercialized' [11]. In its industry review of 2011, Fuel Cell Today wrote that 'in terms of commercial success, the leader by far in terms of units shipments is the PEMFC' contributing $97.03 \%$ of shipments and $73.8 \%$ of MW supplied when compared to other fuel cell types in 2010 [12].

According to Brown et al. [7] Japan will be the first country to make a significant entry into the market for fuel cells for domestic applications. The Japan Gas Association plans to market a high efficiency PEMFC residential cogeneration system with hot water storage tank equipped with back-up burner, a battery for electrical storage and self-diagnostic system; numerous companies are developing residential PEMFC systems [see 8]. To date, more than 13, 307 CHP systems based on PEMFCs and polymer electrolyte fuel cells have been installed in general homes in Japan [13]. In 2006, Aki et al. [14] proposed the implementation of the regional hydrogen energy interchange network (RHEIN) for residential consumption of hydrogen, electricity and heat, with the aim of reducing the cost of installation by sharing of the fuel cells and related equipment between the households. As a follow up, a 2 year demonstration project has been carried out in Osaka City in 2007 - 2009 to evaluate PEM-CHP RHEIN for residential homes [13]. Two cases were examined, namely 6 apartment homes supplied with 3 PEM-CHP units and 4 detached houses supplied with 2 PEM-CHP units; where electricity and water was shared between the homes at the ratio of 1 unit per 2 households. The system consisted of a SMR fuel processor with pressure swing adsorption for purification of hydrogen and PEM fuel cell at maximum supply of $700 \mathrm{~W}$, operated in a grid dependent mode at peak demand. The study has shown that PEM-CHP systems are technologically viable, without any faults or problems experienced during the experimental period. However, problems occurred with high heat loss due to extended hot water sharing pipes. Also, fuel processors showed slow response to the load, were less efficient at partial load and required one hour or more preheating for the catalyst; this problem was partially overcome by introducing hydrogen storage tanks. Overall, the project has demonstrated a reduction in primary energy consumption and $\mathrm{CO}_{2}$ emissions by $6 \%$ and $11 \%$, respectively [13]. In a separate study, Lin et al. [15] also concluded that PEM fuel cell CHP systems are technologically and economically feasible at the current stage, and that additional equipment needed for heat recovery does not contribute much to the overall system financial investment, i.e. does not increase the price significantly.

Compared to other fuel cell types, namely the Solid Oxide Fuel Cell (which can operate on natural gas directly, see [16]), PEMFCs are more demanding since they operate at low temperatures and hence require the feed to be in the form of hydrogen. The presence of $\mathrm{CO}$ and $\mathrm{CO}_{2}$ can have very negative effects on PEM fuel cells; hydrogen dilution with $\mathrm{CO}_{2}$ can cause a decrease in PEM electrical efficiency by 5 to $10 \%$ [17]. Small scale stationary hydrogen generation is of high importance for the advancement of the already most commercialized domestic PEMFC-CHP systems, when compared to other fuel cell types. At present hydrogen is produced almost exclusively through steam methane reforming (SMR), generating a significant amount of atmospheric $\mathrm{CO}_{2}$ emissions [18]. Atilla [17] used the Aspen-HYSYS 3.2 process simulation programme to evaluate methane reformers for residential fuel cell PEMFC-CHP systems. The fuel reformers studied were the autothermal reformer, the steam reformer and a partial oxidation reactor. Steam methane reforming was shown to be the most efficient out of the above for the fuel processors and the overall system efficiency. Hence, for hydrogen powered fuel cells to contribute substantially to a low global carbon economy, generation of environmentally friendly hydrogen is necessary. Mitigating options include the use of Carbon Capture and Storage technology and clean renewable technologies to reduce electricity associated emissions, as well as alternative hydrogen generation method, namely pyrolysis.

\subsection{Carbon Capture and Storage (CCS)}

CCS technology is endorsed by the Intergovernmental Panel on Climate Change and the UK government as a key mitigation option for reducing the emissions from stationary sources such as fossil fuel power stations [19]. CCS includes carbon capture, transportation and storage. Carbon capture involves $\mathrm{CO}_{2}$ capture at the point of generation, the most common methods being by absorption, adsorption, separation by membranes and cryogenic separation. The captured gas mixture is compressed to a supercritical fluid to be transported by pipeline or ship for storage. Storage options include biological storage, ocean storage and mineralization. The main cost is $\mathrm{CO}_{2}$ capture ranging from $24-52$ euro/tonne (equivalent to $£ 19-43$ at the exchange rate of $€ 1=£ 0.8287$ ). Transportation effects can vary depending on pipeline dimensions, $\mathrm{CO}_{2}$ pressure and landscape characteristics, costing from $1-6$ euro/tonne ( $£ 0.8287-5.0)$ per $100 \mathrm{~km}$ pipeline [20]. Different methods of CCS are being addressed, research focusing on economic feasibility and storage safety issues. However, technologies under development focus on large scale $\mathrm{CO}_{2}$ sources such as power stations. Small scale CCS applications have not yet been shown to be viable, major problems occurring in the transport and storage of $\mathrm{CO}_{2}$ [21]. The UK Department of Energy and Climate Change has recognised that reducing the costs and risks associated with CCS are some of the key challenges for CCS deployment in the UK, even for large scale applications [22]. Reduction of CCS costs mainly lies with the capture technology (60 - 80\% of the total cost) [20]. With regards to $\mathrm{CO}_{2}$ transport, the UK CCS Roadmap specifies that new 
pipelines will have to be built, necessitating a whole transport infrastructure. The main challenges lie within storage, including the design, quality of baseline, leakage, monitoring and liability [19], with safety and potential damage to the environment at the top of the list [23].

CCS has not yet been fully demonstrated on a commercial scale, the cost performances reported being based on feasibility studies and pilot projections, which still bear some uncertainty [24]. It is difficult to predict the cost of CCS as it includes the transport and storage of carbon, of which transport is the major variant depending as it does on the siting of the sinks. Studies show that the cost of electricity generation with CCS post 2020 would increase by an average of $45 \%$ [25]. CCS viability for applications in UK electricity generating industries was performed by Element Energy for the Committee on Climate Change [26]. The analysis shows that CCS has the potential to address up to $38 \mathrm{Mt}$ of $\mathrm{CO}_{2}$ emissions per annum in 2030 (decreasing to $37 \mathrm{Mt}$ by 2050) for a cost range of $£ 30$ to $£ 150$ per tonne of $\mathrm{CO}_{2}$ abated. The findings also reveal that the capital cost of the addition of post-combustion capture equipment to gas powered stations almost doubles the total capital cost of the plant; additional complications include gaining permission for a $\mathrm{CO}_{2}$ pipeline route which, combined with other factors is likely to lengthen the overall build time, if not the shut-down period for the power station [26].

\section{4. $\mathrm{CO}_{2}$ free generation of hydrogen}

Hydrocarbon pyrolysis is one alternative method of hydrogen generation, involving a direct decomposition of gaseous hydrocarbons into hydrogen and carbon black [27]. The most promising hydrocarbon is methane [2]. Pyrolysis is optimally environmentally friendly as it does not produce any $\mathrm{CO}_{x}$ $[28,29]$ and is more economical than SMR with carbon capture [30]. The current decomposition methodology employing catalysts is challenging due to catalyst stability considerations [31]. However, problems associated with catalyst sensitivity and deterioration, can be eliminated or diminished by careful application of plasma technology, thereby achieving higher conversion efficiencies and increased specific productivity [27]. Non-thermal plasmas are especially considered to be very promising for organic synthesis applications; however, the present understanding of plasma chemistry is limited and most of the achievements to date have been based on experimental data [32]. They have been successfully applied to hydrogen production from a variety of feedstock: methane, liquid hydrocarbons and biomass. Non-thermal plasma generation methods, including microwave [33], corona discharge [34] and gliding arc [35] have achieved partial oxidation of methane to generate syngas (carbon monoxide and hydrogen). Similarly, atmospheric pressure microwave discharge [36] and pulsed plasma discharges [37-41] have been successfully applied to direct methane decomposition to hydrogen and carbon. Investigations using plasma assisted steam reforming (methane oxidation by water vapour) have been made with such discharge methods as microwave [42] and pulsed corona [27].

Based on the above rationale, our case studies in this work have focused on comparing a Cold Plasma Jet with SMR (the most competitive fuel processor) and Water Electrolysis (another technology at an R\&D stage). The cases are:

(i) The current stage of hydrogen generation with the carbon charge;

(ii) Hydrogen generation post 2020 with the integration of CCS; (iii) Hydrogen generation post 2035 with the integration of clean renewable energy, \&

(iv) PEMFC-CHP integration for direct electricity and heat generation. The UK National Grid energy supply for 2010 is also presented, showing the issues arising.

The aim of this work is to identify the most economical path to eliminate or reduce $\mathrm{CO}_{2}$ emissions for hydrogen production applied to a domestic CHP supply chain.

\section{Methodology}

In order to carry out the above case studies certain data inputs and preliminary calculations are necessary. These are presented here.

\subsection{Data input for national energy supply, emissions and costing calculations}

Firstly, energy supply and emissions data for the UK national grid for 2010 [43] are used as given in Table 1.

Table 1: National grid energy supply and $\mathrm{CO}_{2}$ emissions for 2010

\begin{tabular}{|c|c|c|c|}
\hline National Grid (2010) & \multicolumn{2}{|c|}{ Electricity } & Heat \\
\hline Primary fuel used & NG & Coal & NG \\
\hline Total fuel consumed (GWh) & $371,736^{1}$ & $297,301^{1}$ & \\
\hline Supplied (gross) (GWh) & $171,822^{1}$ & $102,266^{1}$ & \\
\hline Transmission and distribution loss (\%) & \multicolumn{2}{|c|}{$\frac{1}{7.5^{2}}$} & \\
\hline Efficiency $(\%)$ & 42.5 & 34 & \\
\hline Average efficiency (\%) & \multicolumn{2}{|c|}{39} & 90 \\
\hline Total Domestic supply (GWh) & \multicolumn{2}{|c|}{$118681^{3}$} & $350,635^{4}$ \\
\hline Total domestic supply efficiency (\%) & \multicolumn{3}{|c|}{67.6} \\
\hline Average $\mathrm{CO}_{2}$ emissions (tonne/GWh) & \multicolumn{2}{|c|}{$587^{5}$} & $185^{5}$ \\
\hline \multirow{2}{*}{ Domestic $\mathrm{CO}_{2}$ emissions 2010 (Mt) } & \multicolumn{2}{|c|}{69.66} & 64.87 \\
\hline & \multicolumn{3}{|c|}{134.53} \\
\hline
\end{tabular}

All data taken from [61]: ${ }^{1}$ p. 143 , table $5.6 ;{ }^{2}$ p. 167 , table $6 \mathrm{H} ;{ }^{3}$ p138, table $5.2 ;{ }^{4}$ p. 112 , table $4.2 ;{ }^{5}$ p. 126 , table 5.A.

The primary fuel consumed in the form of natural gas (NG) and/or coal for domestic electricity and heat supplied is calculated using the efficiency factors of 0.39 and 0.9 respectively (energy supplied/efficiency factor), shown in Table 1 as an average efficiency. The total efficiency of energy supply (output energy/total primary input energy) taking into account the transmission and distribution losses is $67.6 \%$.

The second set of general data inputs are for the carbon, CCS and renewable energy integration cost calculations. These are given in Table 2 .

Table 2: Data input for cost calculations (relevant references in text below).

\begin{tabular}{|c|c|c|c|}
\hline \multicolumn{2}{|c|}{} & Cost reported & Cost calculated (£) \\
\hline \multicolumn{2}{|c|}{ Natural gas } & $€ 0.0465 / \mathrm{kWh}$ & $0.0385 / \mathrm{kWh}$ \\
\hline \multirow{4}{*}{ Electricity } & $€ 0.1676 / \mathrm{kWh}$ & $0.1389 / \mathrm{kWh}$ \\
\cline { 2 - 4 } & With TC & & $0.1465 / \mathrm{kWh}$ \\
\cline { 2 - 4 } & With CCS & & $0.2014 / \mathrm{kWh}$ \\
\cline { 2 - 4 } & Renewables & & $0.190 / \mathrm{kWh}$ \\
\hline \multicolumn{2}{|c|}{ Methane } & & $0.0480 / \mathrm{kWh}$ \\
\hline \multicolumn{2}{|c|}{ Traded carbon value } & $£ 13$ ton/CO $/ \mathrm{CO}_{2}$ & $0.0130 \mathrm{~kg} / \mathrm{CO}_{2}$ \\
\hline \multicolumn{2}{|c|}{ Non-traded carbon value } & $£ 55$ ton $/ \mathrm{CO}_{2}$ & $0.0550 \mathrm{~kg} / \mathrm{CO}_{2}$ \\
\hline $\begin{array}{c}\text { Solid carbon } \\
\text { Value }\end{array}$ & Low Quality & $£ 200$ ton $/ \mathrm{C}_{\mathrm{S}}$ & $£ 0.2 \mathrm{~kg} / \mathrm{C}_{\mathrm{S}}$ \\
\cline { 2 - 4 } & High Quality & $£ 1000 \mathrm{ton} / \mathrm{C}_{\mathrm{S}}$ & $£ 1 \mathrm{~kg} / \mathrm{C}_{\mathrm{S}}$ \\
\hline
\end{tabular}


The cost of natural gas and electricity are for household ('enduser') energy prices for November 2011 [44]. Consequent hydrogen production calculations assume that the methane feedstock is via natural gas supply from the grid. The constitution of natural gas is 70-90\%; taking the average $80 \%$, the price of methane is $£ 0.048$ per $\mathrm{kWh}$. The Traded Carbon (TC) value is taken for 2010, and under the European Union Emissions Trading Scheme is $£ 13$ tonne $/ \mathrm{CO}_{2}\left(£ 0.013 \mathrm{~kg} / \mathrm{CO}_{2}\right.$ ) [45]. Power station generated electricity in this scenario is part of the traded scheme, and its cost including the TC charge is $£ 0.1465$. The corresponding Non-Traded Carbon (NTC) charge for 2010 under the European Union Emissions Trading Scheme is $£ 55$ tonne $/ \mathrm{CO}_{2}\left(£ 0.055 \mathrm{~kg} / \mathrm{CO}_{2}\right)$. Household emissions from heating and small scale SMR both fall under this scheme [45]. The cost of $\mathrm{CO}_{2}$ for each system described is equal to the amount of $\mathrm{CO}_{2}$ released (tonneCO ${ }_{2}$ ) times the corresponding carbon charge as above ( $\left(\right.$ /tonne $\left.\mathrm{CO}_{2}\right)$.

The reduction in efficiency for coal and gas power plants with CCS is approximately $8 \%$, [24]; hence the net average efficiency for UK grid electricity supply with CCS in 2010 is $31 \%$ (average efficiency of $39 \%$ in Table 1 minus the $8 \%$ reduction). For post 2020 conditions it has been estimated [25] that the cost of electricity generation with CCS will have increased by $45 \%$. Therefore, it can be reasonably assumed that retail electricity will increase by the same rate to $£ 0.2014$ per $\mathrm{kWh}$, as in Table 2. Again it has been estimated that CCS will be able to process up to $38 \mathrm{Mt}$ of $\mathrm{CO}_{2}$ emissions per annum by 2030 [26], which is equivalent to $55 \%$ of total electricity related $\mathrm{CO}_{2}$ emissions for 2010. A US Department of Energy analysis predicts that electricity related $\mathrm{CO}_{2}$ emissions can be reduced by $60 \%$ by 2035 under the Clean Energy Standard. This involves the integration of clean energy: nuclear, hydro, geothermal, municipal waste, solar, wind and biomass [46]. However, this integration will result in a $27 \%$ increase in the electricity price to $£ 0.190$ per $\mathrm{kWh}$.

The $\mathrm{CO}_{2}$ emissions released for domestic electricity and heat supplied amount to energy supplied $(\mathrm{GWh})$ times the average $\mathrm{CO}_{2}$ emissions (tonne/GWh), data given in Table 1. Hence, the total $\mathrm{CO}_{2}$ released in UK for the whole year in 2010 by a) domestic electricity consumption is 69.66 Million tonnes (Mt); these are accounted as TC emissions with a total carbon cost of $£ 905.58$ Millions. The corresponding $\mathrm{CO}_{2}$ emissions from b) domestic heat consumption are $64.87 \mathrm{Mt}$; these are accounted as NTC emissions, the carbon cost being $£ 3,568$ Millions. The retail costs of electricity and natural gas are given in Table 2 as $£ 0.1389$ and $£ 0.0385$ per $\mathrm{kWh}$ respectively. The total annual cost is based on the retail cost of the energy supplied, excluding the carbon cost.

Finally, the Cold Plasma Jet has the potential to generate not only hydrogen, but solid carbon as well. This can be harvested and used in a variety of industrial processes; it has a commercial value of $£ 200$ to $£ 1000$ /tonne depending on the quality [47]. Crystalline carbon structures such as nanotubes are referred to as High Quality Solid Carbon (HQSC), where Low Quality Solid Carbon (LQSC) is the amorphous carbon (e.g. carbon black).

\subsection{Hydrogen generation cost}

The alternative methods of reforming methane or natural gas will require different forms and quantities of energy and will generate different amounts of hydrogen. The cost of generation of hydrogen is the sum of the price of the input fuels, in the form of electricity and or methane/natural gas. For an SMR unit the Non-Traded Carbon Charge (NTCC) is also added. The cost is calculated as follows:

$\mathrm{CkgH}_{2}=\mathrm{F}_{\mathrm{i}} \times \mathrm{C}_{\mathrm{i}}+\mathrm{F}_{\text {elec }} \times \mathrm{C}_{\text {elec }}+\mathrm{X}_{\mathrm{CO}_{2}} \times \mathrm{NTCC}$

The consumption of fuel, whether methane or natural gas, to generate $1 \mathrm{~kg}$ of hydrogen is calculated by dividing the fuel consumption rate $(\mathrm{kg} / \mathrm{s})$ by the hydrogen production rate $(\mathrm{kg} / \mathrm{s})$; the obtained value $(\mathrm{kg})$ is then multiplied by the HHV of the fuel $(\mathrm{kJ} / \mathrm{kg})$ and divided by the factor of 3600 to acquire $\mathrm{F}_{\mathrm{i}}$ $(\mathrm{kWh})$. The consumption of electric energy $\mathrm{F}_{\text {elec }}$ is calculated by dividing the power rating of the reformer $(\mathrm{kWh})$ by the hydrogen production rate $(\mathrm{kg} / \mathrm{s})$. The amount of $\mathrm{CO}_{2}$ generated by the SMR unit $(\mathrm{kg})$ is calculated by dividing the $\mathrm{CO}_{2}$ production rate $(\mathrm{kg} / \mathrm{s})$ by the hydrogen generation rate $(\mathrm{kg} / \mathrm{s})$. The cost of electricity $\mathrm{C}_{\text {elec }}$ is reported in Table 2 for all case studies, i.e. with TC, with CCS and integrated renewables.

\subsection{Reformer input data}

The commercial SMR unit (Helbio APS 1000) generates $2.97 \mathrm{x}$ $10^{-4} \mathrm{~kg} / \mathrm{s}$ hydrogen $\left(1.2 \mathrm{~m}^{3} / \mathrm{h}\right.$ reported $)$ at a natural gas consumption rate of $1.02 \times 10^{-4} \mathrm{~kg} / \mathrm{s}\left(0.43 \mathrm{Nm}^{3} \mathrm{NG} / \mathrm{Nm}^{3} \mathrm{H}_{2}\right.$ reported) and power rating of $0.096 \mathrm{~kW}$. Reformate stream constituents by volume are $74 \% \mathrm{H}_{2}, 24 \% \mathrm{CO}_{2}$ and $2 \% \mathrm{CH}_{4}$ with equivalent $\mathrm{CO}_{2}$ production rate of $7.14 \mathrm{~kg}$ per $\mathrm{kg} \mathrm{H}_{2}$ [48].

The domestic electrolyser technology is at the 'R\&D' stage. The data used for this work was reported for the DOE by EPRI funded research [49] at $6.3 \mathrm{~kW}$ power rating for hydrogen production rate of $3.47 \times 10^{-5} \mathrm{~kg} / \mathrm{s}$ (specified as $1 \mathrm{~kg} / \mathrm{day}$ at $8 \mathrm{~h} /$ day operation).

Cold Plasma conversion of methane to hydrogen is also at the $\mathrm{R} \& \mathrm{D}$ stage. The data used for this work are from the nonthermal plasma jet experiments reported by $\mathrm{Li}$ et al. [38]. The methane consumption rate is calculated using the reported mass flow rate given of $880 \mathrm{ml} / \mathrm{min}$ and methane conversion rate of $60.97 \%$ [38]:

$\mathrm{c}_{\mathrm{CH}_{4}}=\mathrm{n}_{\mathrm{CH}_{4}} \times \operatorname{Conv}_{\mathrm{CH}_{4}}$

The hydrogen generation rate is calculated from the reported hydrogen selectivity of $89.3 \%$ [38] and the methane conversion rate:

$$
\mathrm{p}_{\mathrm{H}_{2}}=\mathrm{c}_{\mathrm{CH}_{4}} \times 2 \times \mathrm{S}_{\mathrm{H}_{2}}
$$

The summary of the important parameters for SMR, water electrolysis and cold plasma jet specifications is given in Table 3 , where the fuel conversion efficiency for the system is calculated as follows:

$\mathrm{E}=\frac{\mathrm{p}_{\mathrm{H}_{2}} \times \mathrm{HHV}_{\mathrm{H}_{2}}}{\mathrm{c}_{\mathrm{i}} \times \mathrm{HHV}_{\mathrm{i}}+\mathrm{W}} \times 100$

Table 3: Data inputs for SMR, WE and CPJ reformers

\begin{tabular}{|c|c|c|c|}
\hline & SMR & WE & CPJ \\
\hline Power rating $(\mathrm{kW})$ & 0.096 & 6.3 & 0.07 \\
\hline Fuel consumption $(\mathrm{kg} / \mathrm{s})$ & $1.02 \times 10^{-4}$ & & $6.4 \times 10^{-6}$ \\
\hline $\mathrm{H}_{2}$ generation $(\mathrm{kg} / \mathrm{s})$ & $2.97 \times 10^{-4}$ & $3.47 \times 10^{-5}$ & $1.43 \times 10^{-6}$ \\
\hline $\mathrm{CO}_{2}\left(\mathrm{~kg} \mathrm{CO}_{2} / \mathrm{kg} \mathrm{H}\right)$ & 7.14 & & \\
\hline Conversion efficiency $(\%)$ & 77.1 & 78.1 & 47.7 \\
\hline
\end{tabular}




\subsection{FC-CHP system specifications}

The final comparison study involving an integrated Fuel Cell/CHP system (FC-CHP), uses as input data the specifications for the commercial PEMFC CHP system developed by Ballard MK5-E PEMFC stack [50]. These, together with other (calculated) data are given in Table 4 .

\section{Table 4: Fuel Cell CHP system}

\begin{tabular}{|l|c|}
\hline \multicolumn{2}{|c|}{ Fuel Cell Specifications (Ballard MK5-E PEMFC stack) } \\
\hline Temperature & $70{ }^{\circ} \mathrm{C}$ \\
\hline Max output electric & $4 \mathrm{~kW}$ \\
\hline Max thermal recovered & $3 \mathrm{~kW}$ \\
\hline Power to heat ratio & 1.33 \\
\hline Electrical efficiency & $45 \%$ \\
\hline Thermal efficiency & $35 \%$ \\
\hline CHP efficiency & $80 \%$ \\
\hline
\end{tabular}

Electricity generation from $1 \mathrm{~kg}$ hydrogen input using the data from Table 4 is calculated as follows:

$\mathrm{W}=\mathrm{E} \times \mathrm{HHV}_{\mathrm{H}_{2}} \times \mathrm{p}_{\mathrm{H}_{2}}$

and is equal to $17.735 \mathrm{kWh}$. The power to heat ratio is 1.33 hence, the heat generated is $13.301 \mathrm{kWh}$.

\section{Results and Discussion}

\subsection{UK National grid 2010 conditions}

Figure 1 summarises diagrammatically the UK energy supply from the national grid in 2010 together with the costing and the associated $\mathrm{CO}_{2}$ emissions calculated based on the discussion and information in section 2.1.

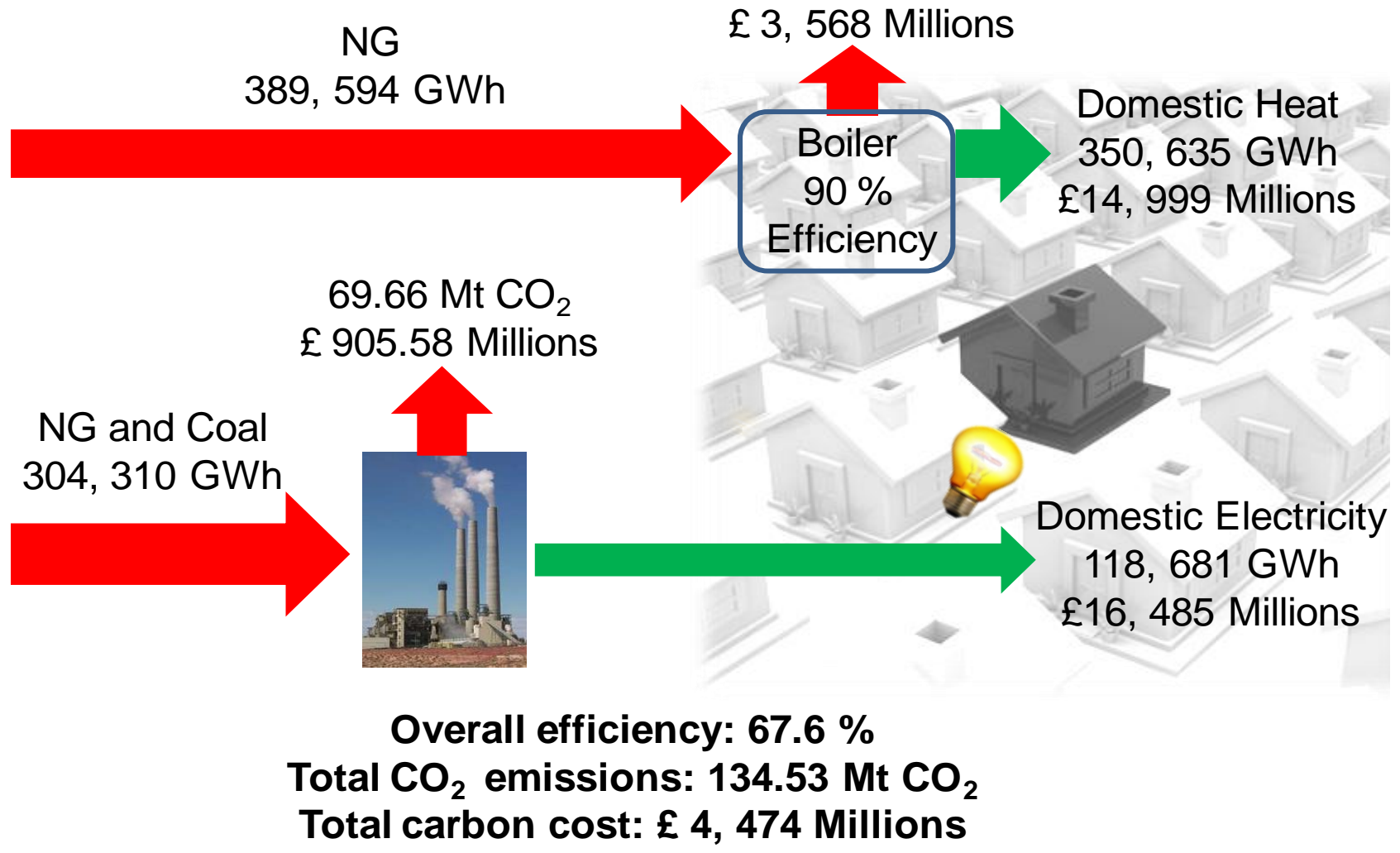

Figure 1: Domestic energy supply from the National Grid in 2010 and associated carbon dioxide emissions. Notes: (i) the costing is for the retail price for total energy consumed; (ii) the heat and electricity cost does not include the stated carbon charge

Using the same 2010 data, but incorporating CCS into the system, leads to Figure 2. If CCS becomes commercially viable as planned post 2020, over half of the emissions from the UK electricity supply sector can be eliminated. However, this brings a financial penalty to the power station and the consumer. The overall process efficiency is decreased and the retail cost of electricity increases steeply. As discussed in the introduction, since CCS is not viable at small scales in the foreseeable future, the emissions from domestic heat generation cannot be reduced by CCS. The integration of clean energy can reduce the emissions by $60 \%$ at the penalty of a 27 $\%$ increase in the price of electricity to $£ 0.190$ per kWh. 


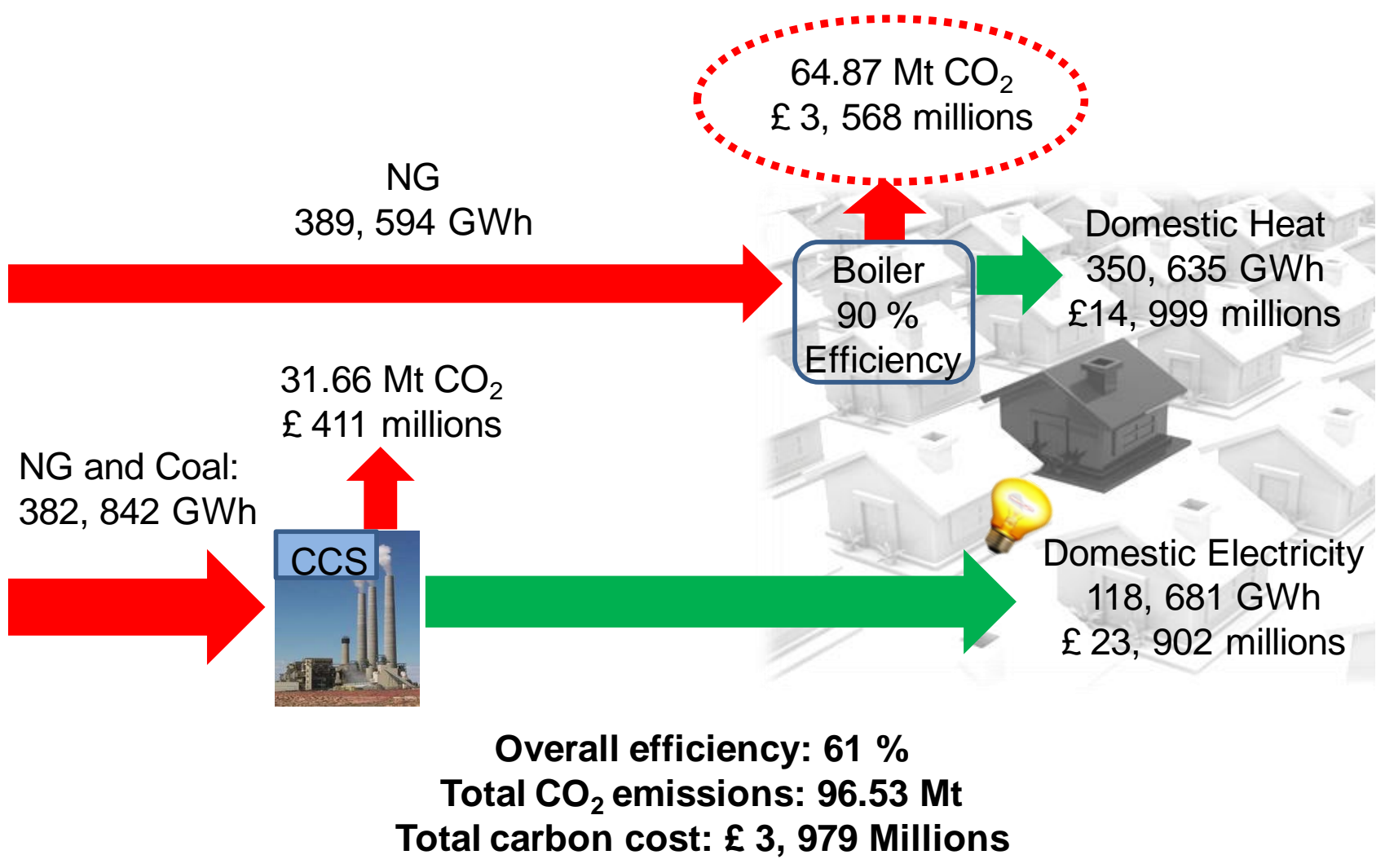

Figure 2: Domestic energy supply from the National Grid using 2010 data with future anticipated CCS. Notes: (i) the costing is for the retail price for total energy consumed; (ii) the heat and electricity cost does not include the stated carbon charge

\begin{abstract}
3.2. Comparison of current hydrogen generation systems: effect of solid carbon credit

The rationale of this study is to compare the three hydrogen generation alternatives of Steam Methane Reforming (SMR), Water Electrolysis (WE) and Cold Plasma Jet (CPJ). Calculations for current conditions (data for 2010) and taking hydrogen as the end product, leads to the results shown in Figure 3 and Table 5. CPJ is competitive with SMR in terms of $\mathrm{CO}_{2}$ emissions. The overall hydrogen cost is lowest using SMR, with CPJ coming second.
\end{abstract}

According to Bartels et al. [51] the approximate cost of large scale hydrogen production using SMR was $2.48-3.17$ US $\$ / \mathrm{kg}$ of hydrogen in 2007 (equivalent to $£ 1.6-2.05$ at exchange rate of $\$ 1=£ 0.6464)$. For commercial large scale WE the cost was estimated to be in excess of 8 US $\$ / \mathrm{kg}$ [52] (equivalent to £5.17). As expected, small scale hydrogen generation using both SMR and WE is a more costly process than for large scale generation. However, it is also necessary to consider the requisite extra costs involved in implementing a new hydrogen infrastructure for transport, and storage for supplying domestic districts with hydrogen for FC-CHP. Further, the emissions from a large scale SMR plant have been estimated to be 13.7 $\mathrm{kg} \mathrm{CO}_{2}$ per $\mathrm{kg}$ of hydrogen [53], while the small scale commercial SMR unit in this study only generates $7.67 \mathrm{~kg} \mathrm{CO}_{2}$ per kg hydrogen in total.

When the value of the solid carbon product of CPJ [47] is taken into account, the effective hydrogen cost reduces from 5.304 (no credit) to 4.704 and 2.304 for LQSC and HQSC respectively. LQSC and HQSC correspond to the respective levels of $£ 0.2$ and $£ 1$ per $\mathrm{kg} \mathrm{C}_{\mathrm{s}}$ of Table 2. The HQSC value makes CPJ directly competitive with SMR. The striking effect of $C_{s}$ credit (especially for HQSC) holds for all following cases of this study. WE shows substantially lower potential than CPJ in terms of hydrogen generation cost and associated $\mathrm{CO}_{2}$ emissions.

Table 5: Hydrogen generation under current conditions

\begin{tabular}{|c|c|c|c|c|c|}
\hline & \multirow{2}{*}{ SMR } & \multirow{2}{*}{ WE } & \multicolumn{3}{|c|}{ CPJ } \\
\cline { 5 - 7 } & & & & LQSC & HQSC \\
\hline Conversion Efficiency (\%) & 77.7 & 78.1 & 47.7 & 47.7 & 47.7 \\
\hline System Efficiency (\%) & 75.6 & 30.45 & 37.9 & 37.9 & 37.9 \\
\hline Hydrogen cost (£/kg) & 2.442 & 7.388 & 5.304 & 4.704 & 2.304 \\
\hline $\mathbf{C O}_{2}$ emissions (kg CO$/ \mathbf{k g ~ \mathbf { H } _ { 2 } )}$ & 7.67 & 29.60 & 7.98 & 7.98 & 7.98 \\
\hline
\end{tabular}

3.3. Comparison of hydrogen generation systems: post-2020 scenario with CCS

For a post-2020 scenario allowing for anticipated CCS, results of the comparative system analysis of the alternatives are shown in Figure 4 and Table 6. 

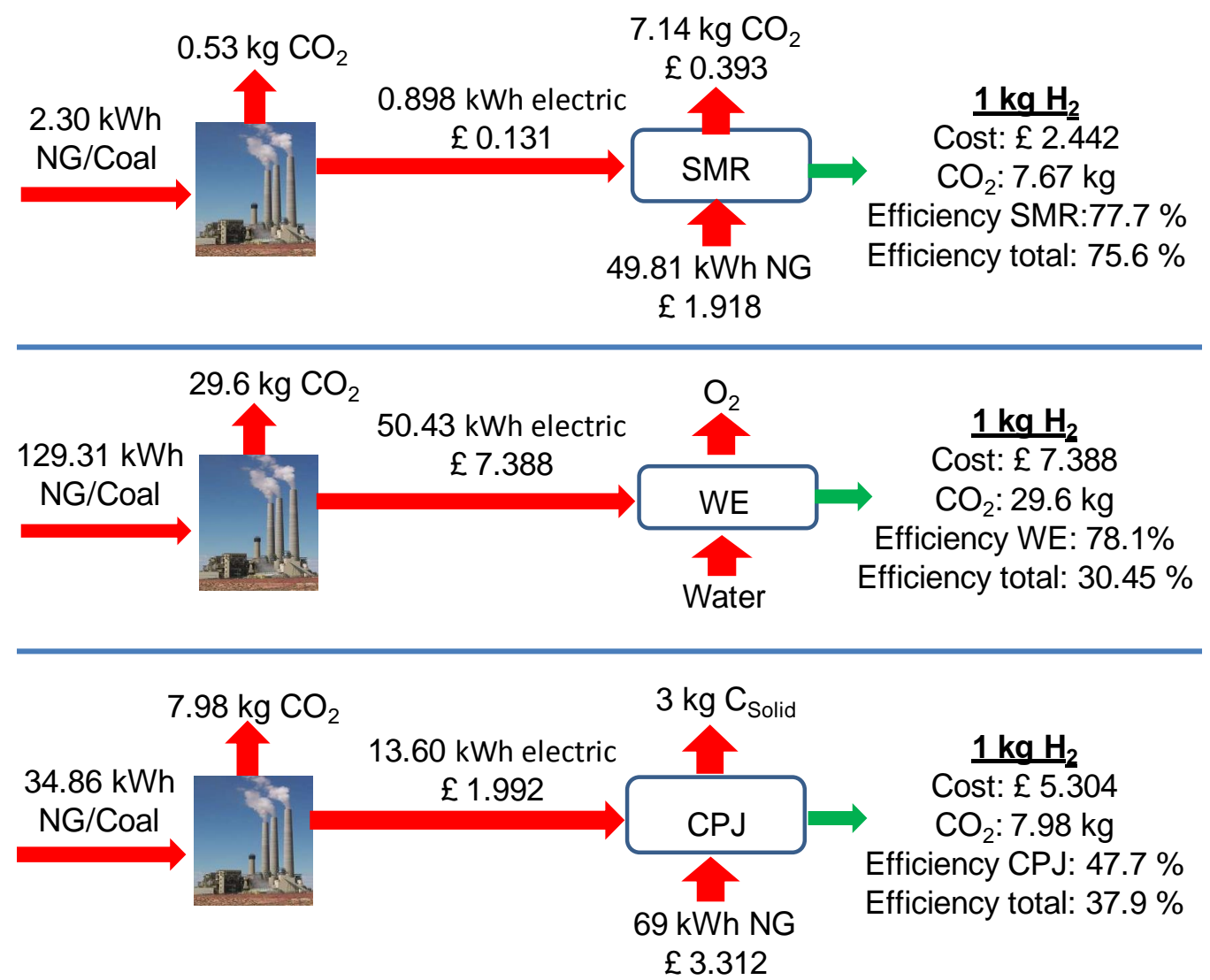

Figure 3: Summary diagrams for system analysis for hydrogen generation under current conditions, carbon charges included
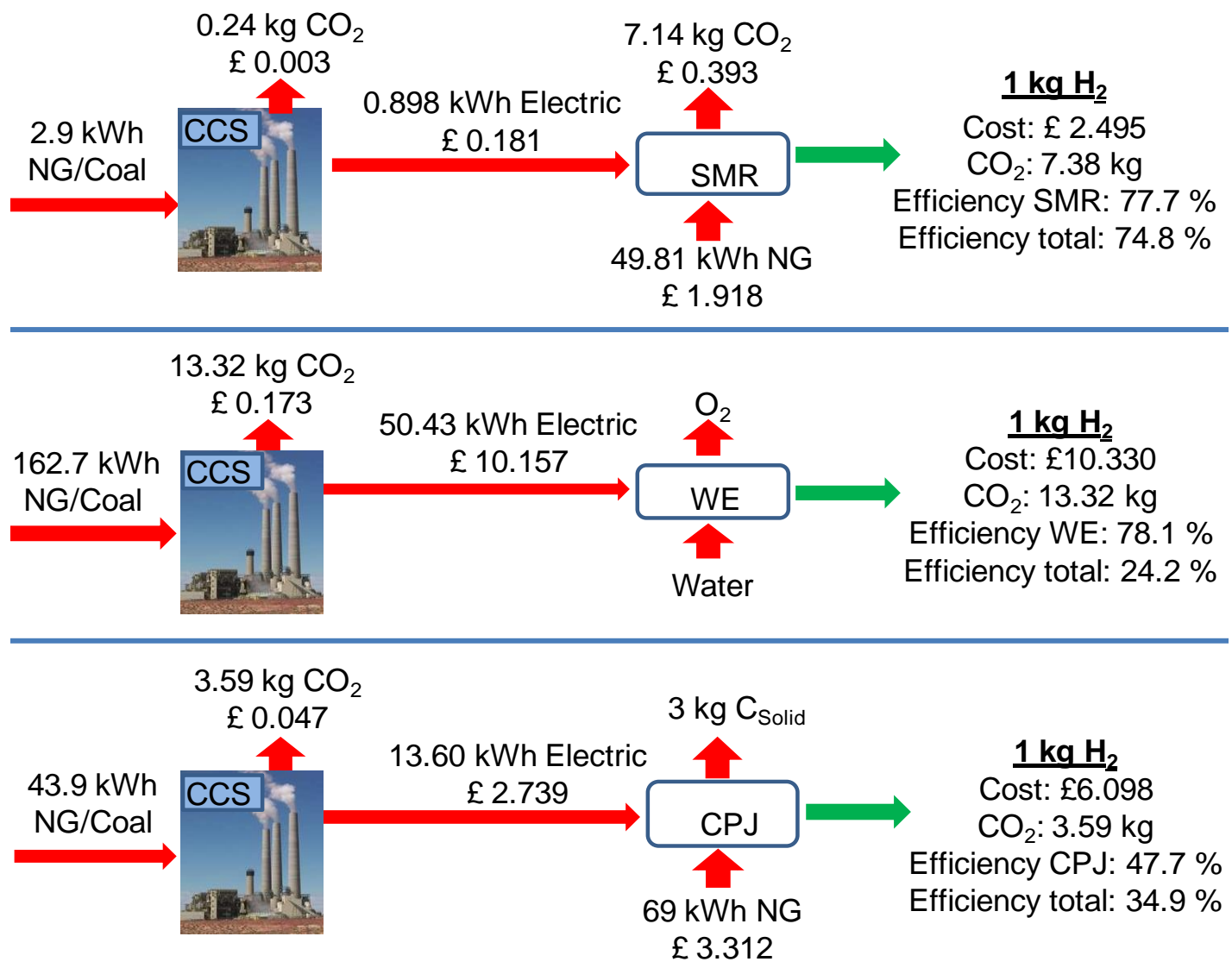

Figure 4: Hydrogen generation post 2020 with CCS. 
Table 6: Hydrogen generation post 2020 with CCS

\begin{tabular}{|c|c|c|c|c|c|}
\hline & \multirow{2}{*}{ SMR } & \multirow{2}{*}{ WE } & \multicolumn{3}{|c|}{ CPJ } \\
\cline { 5 - 6 } & & & LQSC & HQSC \\
\hline Conversion Efficiency (\%) & 77.7 & 78.1 & 47.7 & 47.7 & 47.7 \\
\hline System Efficiency (\%) & 74.8 & 24.2 & 34.9 & 34.9 & 34.9 \\
\hline Hydrogen cost (£/kg) & 2.495 & 10.320 & 6.098 & 5.498 & 3.098 \\
\hline $\mathbf{C O}_{2}$ emissions $\left(\mathbf{k g} \mathbf{C O}_{2} / \mathbf{k g ~ \mathbf { H } _ { 2 } )}\right.$ & 7.38 & 13.32 & 3.59 & 3.59 & 3.59 \\
\hline
\end{tabular}

The addition of CCS has a very small impact on SMR as the electricity consumption is very low and the majority of the emissions associated are from the SMR itself. Since the $\mathrm{CO}_{2}$ emissions for WE and CPJ are only electricity related, in both cases a $55 \%$ decrease is seen. For this scenario, though, the hydrogen generation cost for WE increases drastically by nearly $£ 3$ per $\mathrm{kg} \mathrm{H}_{2}$ as all of the primary energy for WE comes in the form of electricity. The hydrogen cost using CPJ only increases by $£ 0.806$ per $\mathrm{kg} \mathrm{H}_{2}$ as CPJ is not primarily electricity dependent, the majority of energy used being in the form of methane. $\mathrm{CO}_{2}$ emissions for $\mathrm{CPJ}$ in this scenario are nearly half those of SMR; for WE the $\mathrm{CO}_{2}$ emissions are again the highest.
3.4. Comparison hydrogen generation systems: post-2035 scenario with renewable integrated electricity generation

Another important possible scenario is for 2035 when the electricity system is planned to be integrated with renewable sources. Results of the system analysis are shown in Figure 5 and Table 7. With this scenario little effect is seen for the SMR system vis a vis the post-2020 scenario but WE and CPJ both have somewhat improved with lower emissions and cost.

Table 7: Hydrogen generation post 2035 with clean renewable energy integration

\begin{tabular}{|c|c|c|c|c|c|}
\hline & \multirow{2}{*}{ SMR } & \multirow{2}{*}{$\mathbf{W E}$} & \multicolumn{3}{|c|}{ CPJ } \\
\hline & & & & LQSC & HQSC \\
\hline Conversion Efficiency (\%) & 77.7 & 78.1 & 47.7 & 47.7 & 47.7 \\
\hline System Efficiency (\%) & 77.4 & 60.5 & 45.6 & 45.6 & 45.6 \\
\hline Hydrogen cost $(\mathfrak{f} / \mathbf{k g})$ & 2.485 & 9.736 & 5.937 & 5.337 & 2.937 \\
\hline $\mathrm{CO}_{2}$ emissions $\left(\mathrm{kg} \mathrm{CO}_{2} / \mathrm{kg} \mathrm{H}_{2}\right)$ & 7.35 & 11.84 & 3.19 & 3.19 & 3.19 \\
\hline
\end{tabular}
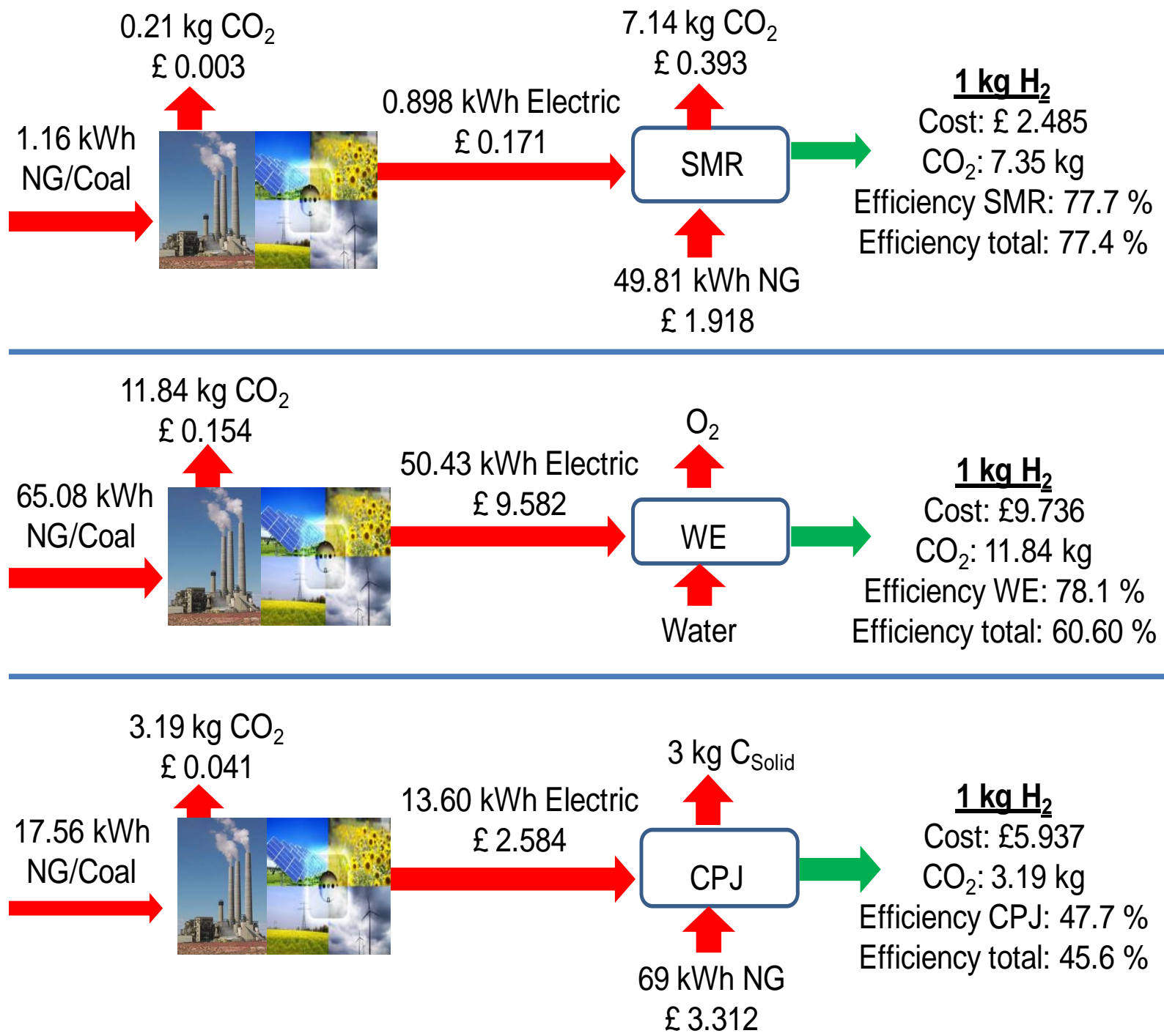

Figure 5: Hydrogen generation post 2035 with clean renewable energy integration 
3.5. Comparison of hydrogen generation systems: combination of an integrated FC-CHP system

The most important requirements for stand-alone power generation are the independence of the system from the electricity grid and the use of available fuels and infrastructure such as natural gas [48]. Since the electricity consumption for both the SMR and CPJ is lower than that generated by a fuel cell, using a combined PEMFC-CHP system, means that SMR and $\mathrm{CPJ}$ can be self sustained and decentralised from the electricity grid. Results of the system analysis are shown in Figure 6 and Table 8.The CPJ system is convincingly the most attractive: $\mathrm{CO}_{2}$ emissions have been removed completely and energy generation costs for the $H Q C_{s}$ case are better than onequarter that for SMR.

In summary CPJ handsomely outperforms the current commercial SMR and is very substantially better than WE. With the production of High Quality carbon, the cost of energy using CPJ is 4 times lower when compared to the SMR system.
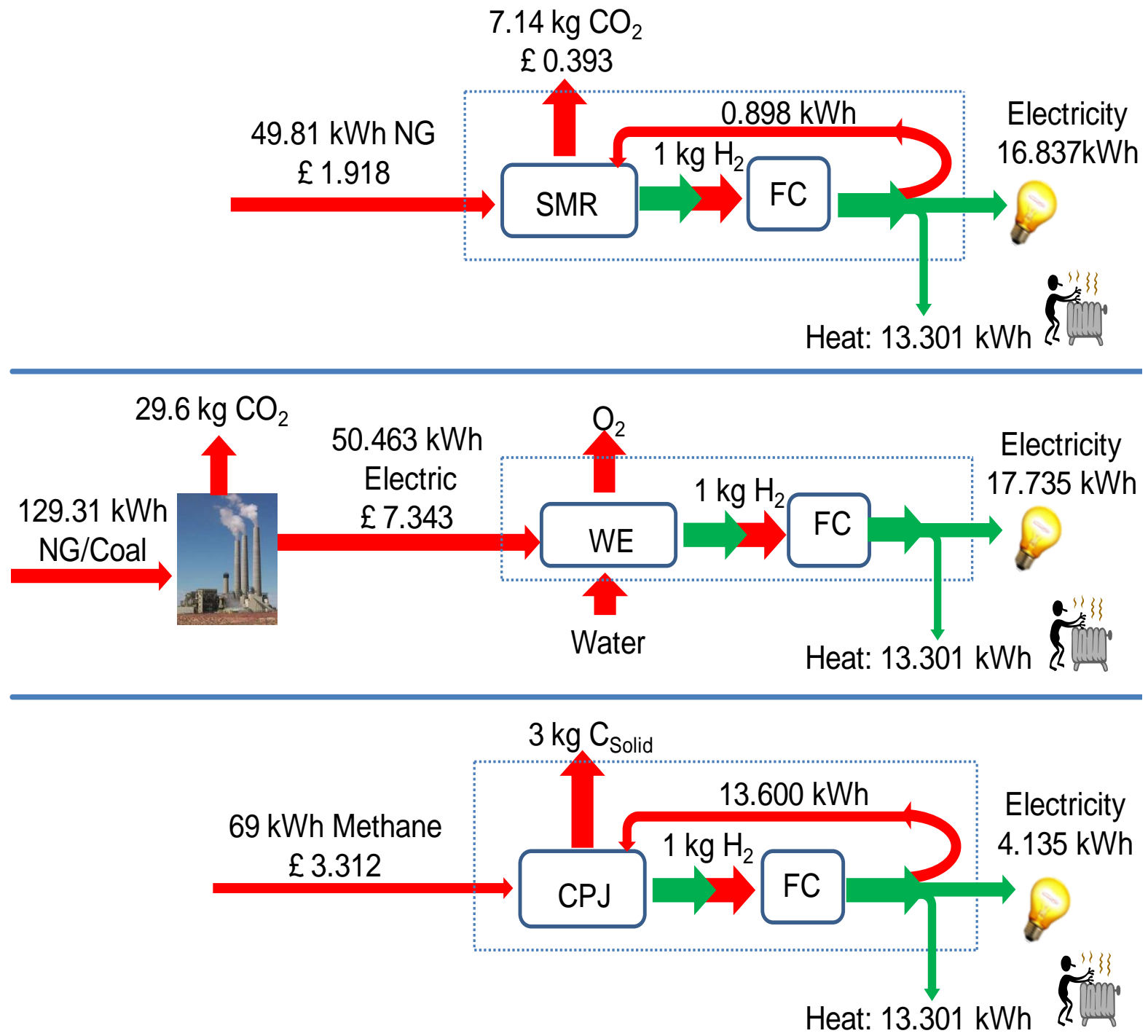

Figure 6: Summary of the system analysis with integrated FC-CHP system

Table 8: System analysis with integrated FC-CHP

\begin{tabular}{|l|l|l|l|l|l|}
\hline & \multirow{2}{*}{ SMR } & \multirow{2}{*}{ WE } & \multicolumn{3}{|c|}{ CPJ } \\
\cline { 5 - 7 } & & & & LQSC & HQSC \\
\hline Conversion Efficiency (\%) & 77.7 & 78.1 & 47.7 & 47.7 & 47.7 \\
\hline System Efficiency (\%) & 60.5 & 24 & 25 & 25 & 25 \\
\hline Energy Cost (£/kWh) & 0.077 & 0.237 & 0.190 & 0.156 & 0.018 \\
\hline $\mathbf{C O}_{2}$ emissions (kg CO$\left./ \mathbf{k g ~ ~ H _ { 2 }}\right)$ & 7.14 & 29.6 & 0 & 0 & 0 \\
\hline
\end{tabular}

\section{Conclusions and future work}

While the UK national grid operates at a high overall efficiency of $67 \%$ for supplying domestic electricity and heat, even with the anticipated use of CCS technology, emissions from domestic heat generation cannot be eliminated.

For all scenarios analysed, CPJ is more competitive than WE in hydrogen cost and $\mathrm{CO}_{2}$ emissions. Indeed, combining $\mathrm{CPJ}$ and FC-CHP can eliminate emissions altogether. $\mathrm{CPJ}$ also produces potentially considerably valuable solid carbon and means the technology of CPJ closely competes economically with that of commercialised SMR in terms of hydrogen generation costs. If 
high quality carbon is produced, CPJ integrated with $\mathrm{FC}$-CHP is not only emission free, but substantially out-competes SMR on the cost of energy. This is a most attractive prospect, considering plasma technology is still at the $R \& D$ stage.

Overall, it is clear that distributed hydrogen generation could become very competitive, with CPJ having a high potential for economic and clean energy generation. An important final point is this: given that the CPJ system, unlike the SMR and WE systems, is emission-free in terms of the atmosphere, it is not sensitive to future political and technological uncertainties and decision changing in $\mathrm{CO}_{2}$-related costing.

Future system analysis work could include a feasibility study for applying the FC-CHP system to meet the daily loads for domestic electricity and heat in the UK as a whole. Experimental work should include developing a non-thermal plasma reactor to reduce electrical power consumption and enhance overall efficiency. Different electrode configurations and designs should be tested to optimise hydrogen production and ensure effective solid carbon removal.

\section{Nomenclature}

\begin{tabular}{|c|c|}
\hline Conv & Conversion rate of a compound (\%) \\
\hline $\mathrm{C}$ & Cost $(\mathfrak{f})$ \\
\hline $\mathrm{c}$ & Consumption rate of fuel $(\mathrm{kg} / \mathrm{s})$ \\
\hline $\mathrm{E}$ & Energy efficiency $(\%)$ \\
\hline $\mathrm{F}$ & Fuel $(\mathrm{kWh})$ \\
\hline HHV & Higher heating value $(\mathrm{kJ} / \mathrm{kg})$ \\
\hline $\mathrm{n}$ & Mass flow rate of a compound $(\mathrm{kg} / \mathrm{s})$ \\
\hline $\mathrm{W}$ & Electric energy $(\mathrm{kJ} / \mathrm{s})$ \\
\hline $\mathrm{p}$ & Production rate of fuel $(\mathrm{kg} / \mathrm{s})$ \\
\hline S & Selectivity (\%) \\
\hline $\mathrm{X}$ & Amount of compound to generate $1 \mathrm{~kg} \mathrm{H}_{2}(\mathrm{~kg})$ \\
\hline $\mathrm{Y}$ & Amount of fuel to generate $1 \mathrm{~kg} \mathrm{H}_{2}(\mathrm{kWh})$ \\
\hline
\end{tabular}

\section{Subscripts}

$\begin{array}{ll}\mathrm{CH}_{4} & \text { Methane } \\ \mathrm{CO}_{2} & \text { Carbon dioxide } \\ \text { elec } & \text { Electrical }(\mathrm{kWh}) \\ \mathrm{H}_{2} & \text { Hydrogen } \\ \mathrm{i} & \text { Fuel: methane or natural gas }\end{array}$

\begin{tabular}{ll}
\multicolumn{2}{l}{ Abbreviations } \\
CCS & Carbon Capture and Storage \\
CHP & Combined Heat and Power \\
CPJ & Cold Plasma Jet \\
FC & Fuel Cell \\
HQSC & High Quality Solid Carbon \\
LQSC & Low Quality Solid Carbon \\
Mt & Million tonnes
\end{tabular}

$\begin{array}{ll}\text { NG } & \text { Natural Gas } \\ \text { NTC } & \text { Non-Traded Carbon } \\ \text { PEMFC } & \text { Proton Exchange Membrane Fuel Cell } \\ \text { R\&D } & \text { Research and Development } \\ \text { RHEIN } & \text { Regional Hydrogen Energy Interchange Network } \\ \text { SMR } & \text { Steam Methane Reforming } \\ \text { TC } & \text { Traded Carbon } \\ \text { WE } & \text { Water Electrolysis }\end{array}$

\section{Acknowledgments}

We gratefully acknowledge the valuable advice of Professor Colin Snape of the University of Nottingham, UK

\section{References}

[1] Aleknaviciute I, Karayiannis TG, Collins MW, Xanthos C. Plasma-assisted decomposition of gaseous propane to produce $\mathrm{CO}_{\mathrm{x}}$ free hydrogen. Int. J. Low-Carbon Technologies 2012; doi: 10.1093/ijlct/cts015.

[2] Edwards PP, Kuznetsov VL, David WIF, Brandon NP. Hydrogen and fuel cells: towards a sustainable energy future. Energy Policy 2008;36:4356.

[3] Dorian JP, Franseen HT, Simbeck DR. Global challenges in energy. Energy Policy 2006;34:1984.

[4] Monahan J, Powell JC. A comparison of the energy and carbon implications of new systems of energy provision in new build housing in the UK. Energy Policy 2010;39:290.

[5] EC. Hydrogen energy and fuel cells: A vision of our future. European Commission 2003; EUR 20719 EN.

[6] IPHE. Hydrogen and fuel cell global commercialization \& development update. International Partnership for hydrogen and fuel cells in the economy 2010.

[7] Brown JE, Hendry CN, Harborne P. An emerging market in fuel cells? Residential combined heat and power in four countries. Energy Policy 2007;35:2173.

[8] Onovwiona HI, Ugursal VI. Residential cogeneration systems: review of the current technology. Renew. Sustain. Energy Rev. 2006: 10:389.

[9] Mekhilef S, Saidur R, Safari A. Comparative study of different fuel cell technologies. Renew. Sustain. Energy Rev. 2011;doi: 10.1016/j.rser.2011.09.020.

[10] Venturelli L, Santangelo PE, Tartarini P. Fuel cell and traditional technologies. Part II: Experimental study on dynamic behaviour of PEMFC in stationary power generation. Appl. Thermal Eng. 2009;29:3469.

[11] Barelli L, Bidini G, Gallorini F, Ottaviano A. Dynamic analysis of PEMFFC-based CHP systems for domestic application. Appl. Energy 2012;91:13.

[12] Fuel Cell Today (2011). The fuel cell today industry review 2011;40. (http://fuelcelltoday.com/analysis/industryreview/2011/the-industry-review-2011).

[13] Aki H, Taniguchi Y, Tamura I, Kegasa A, Hayakawa H, Ishikawa Y, Ymamoto S, Sugimoto I. Fuel cells and 
energy networks of electricity, heat, and hydrogen: A demonstration in hydrogen-fueled apartments. Int. J. Hydrogen Energy 2012;37:1204.

[14] Aki H, Yamamoto S, Kondoh J, Maeda T, Yamaguchi H, Murata A, Ishii I. Fuel cells and energy networks of electricity, heat and hydrogen in residential areas. Int. J. Hydrogen Energy 2006;31:967.

[15] Lin JCM, Yan ZA, Wang SK. Technological development of a PEMFC-based CHP system. ESD, Thailand, 2010.

[16] Yi Y, Rao AD, Brouwer J, Samuelsen GS. Fuel flexibility study of an integrated $25 \mathrm{~kW}$ SOFC reformer system. J. Power Sources 2005;144:67.

[17] Atilla E. Investigation of hydrocarbon refomring processes for micro-cogeneration systems. Int. J. Hydrogen Energy 2008;33:7084.

[18] Abbas HF, and Daud WMAW. Hydrogen production by methane decomposition: A review. Int. J. Hydrogen Energy 2010;35:1160.

[19] Gough C, Mander S, Haszeldine S. A roadmap for carbon capture and storage in the UK. Int. J. Greenhouse Gas Control 2012;4: 1

[20] Pires JCM, Martins FG, Alvin-Ferraz MCM, Simoes M. Recent developments on carbon capture and storage: An overview. Chem. Eng. Research and Design 2011;89:1446.

[21] Tokoro T, Kato T, Tanaka Y, Kato K, Negishi A, Nozaki K. Feasibility of distributed carbon capture and storage (DCCS). Energy Conv. and Mang. 2011;52:2509.

[22] DOECC. CCS Roadmap: Supporting deployment of carbon capture and storage in the UK. April, 2012.

[23] Koorneef J, Ramirez A, Turkenburg W, Faaij A. The environmental and risk assessment of $\mathrm{CO}_{2}$ capture, transport and storage - An evaluation of the knowledge base. Progress in Energy and Combustion Science 2012;38:62.

[24] IEA. Cost and performance of carbon dioxide capture and storage from power generation, 2011.

[25] ZEP (European Technology Platform for Zero Emissions Fossil Fuel Power Plants). The cost of $\mathrm{CO}_{2}$ capture, transport and storage.

[26] EECCC (Element Energy for the Committee on Climate Change). Potential for the application of CCS to UK industry and natural gas power generation, 2010. (http://downloads.theccc.org.uk.s3.amazonaws.com/0610/ pr_supporting_research_element_Energy_CCS_on_gas_a nd_industry.pdf)

[27] Fridman A. Plasma Chemistry. Cambridge: Cambridge University Press 2008.

[28] Dufour J, Galvez JL, Serrano DP, Moreno J, Martinez G. Life Cycle Assessment of hydrogen production by methane decomposition using carbonaceous catalysts. Int. J. Hydrogen Energy 2010;35:1205.

[29] Dufour J, Serrano DP, Galvez JL, Moreno J, Garcia C. Life Cycle Assessment of processes for hydrogen production. Environmental feasibility and reduction of greenhouse gas emissions. Int. J. Hydrogen Energy 2009;34:1370.
[30] Bockris JOM. The origin of ideas on hydrogen economy and its solution to the decay of the environment. Int. J. Hydrogen Energy 2002;27:731.

[31] Rakib MA, Grace JR, Lim CJ, Elnashaie SSEH, Ghiashi B. Steam reforming of propane in a fluidized bed membrane reactor for hydrogen production. Int. J. Hydrogen Energy 2010;35:6276.

[32] Petipas G, Rollier JD, Darmon A, Gonzalez-Aguilar J, Metkemeijer R, Fulcheri L. A comparative study of nonthermal plasma assisted reforming technologies. Int. J. Hydrogen Energy 2007;32:2848.

[33] Tsai C-H, Hsien T-H, Shin M, Huang Y-J, Wei T-C. Partial oxidation of methane to synthesis gas by a microwave plasma torch. Env. Energy Eng. 2005;51:2853.

[34] Kado S, Skine Y, Nozaki T, Okazaki K. Diagnosis of atmospheric pressure low temperature plasma and application to high efficient methane conversion. Catalysis Today 2004;89:47.

[35] Sreethawong T, Thakonpatthanakun P, Chavadej S. Partial oxidation of methane with air for synthesis.Int. J. Hydrogen Energy 2007;32:1067.

[36] Tsai C-H and Chen K-T. Production of hydrogen and nano carbon powders from direct plasmalysis of methane. Int. J. Hydrogen Energy 2009;34:833.

[37] Li X-S, Zhu A-M, Wang K-J, Xu Y, Song Z-M. Methane conversion to $\mathrm{C}_{2}$ hydrocarbons and hydrogen in atmospheric non-thermal plasmas generated by different electric discharge techniques. Catalysis Today 2004;98:617.

[38] Li D, Li X, Bai M, Tao X, Shang S, Dai X, Yin Y. $\mathrm{CO}_{2}$ reforming of $\mathrm{CH}_{4}$ by atmospheric pressure glow discharge: A high conversion ability. J. Fuel. Chem. Technol. 2009;34:308.

[39] Da Silva CF, Ishikawa S, Alves JC, Marninelli AE. Production of hydrogen from methane using pulsed plasma and simultaneous storage to titanium sheet. Int. J. Hydrogen Energy 2006;31:49.

[40] Yao S, Nakayama A, Suzuki E. Acetylene and hydrogen from pulsed plasma conversion of methane. Catalysis Today 2001;71:219.

[41] Yao SL, Suzuki E, Meng N, Nakayama A. A highefficiency reactor for the pulsed plasma conversion of methane. Plasma Chemistry and Plasma Processing 2002;22:225.

[42] Wang Y-F, Tsai C-H, Chang W-Y, Kuo Y-M. Methane steam reforming for producing hydrogen in an atmospheric-pressure microwave plasma reactor. Int. J. Hydrogen Energy 2010;35:135.

[43] DOECC - Department of Energy and Climate Change. Digest of UK energy statistics 2011. 2010; ISBN 9780115155277.

[44] Europe's Energy

Portal (http://www.energy.eu/\#Domestic-Elec).

[45] DOECC. A brief guide to the carbon valuation methodology for UK policy appraisal.2011.

[46] EIA, US Department of Energy. Analysis of impacts of a clean energy standard. 2011. 
[47] http://www.alibaba.com/showroom/granular-activatedcarbon.html.

[48] Calo E, Giannini A, Monteleone G. Small stationary reformers for $\mathrm{H}_{2}$ production from hydrocarbons. Int. J. Hydrogen Energy 2010;35:9828.

[49] Rastler D. EPRI Hydrogen Briefing to DOE. Electric power Research institute 2008 (http://www1.eere.energy.gov/hydrogenandfuelcells/prod uction/electro_processes.html).

[50] Laurencelle F, Chahine R, Hamelin J, Agbossou K, Fournier M, Bose TK, Laperriere A. Characterization of a
Ballard MK5-E Proton Exchange Membrane Fuel Cell StackFuel Cells. Fuel Cells 2001;1:66.

[51] Bartels JR, Pate MB, Olson NK. An economic survey of hydrogen production from conventional and alternative energy sources. Int. J. Hydrogen Energy 2010;35:8371.

[52] Balat M. Potential importance of hydrogen as a future solution to environmental and transportation problems. Int. J. Hydrogen Energy 2008;33:4013.

[53] Muradov NZ, Veziroğlu TN. From hydrocarbon to hydrogen-carbon to hydrogen economy. Int. J. Hydrogen Energy 2005;30:225. 